\title{
Transcription of (pro)renin mRNA in the rat adrenal cortex, and the effects of ACTH treatment and a low sodium diet
}

\author{
M M Ho and G P Vinson \\ Department of Biochemistry, St Bartholomew's and The London School of Medicine \& Dentistry, Queen Mary \& Westfield College, Mile End Road, \\ London E1 4NS, UK \\ (Requests for offprints should be addressed to G P Vinson)
}

(M M Ho is now at the Rayne Institute, Department of Medicine, University College London Medical School, 5 University Street, London WC1 6JJ, UK)

\begin{abstract}
Transcription of the (pro)renin gene in the adult rat adrenal gland was studied by non-isotopic in situ hybridization.

In glands from control (untreated) animals, transcription was relatively sparse, and occurred mostly in the outer zona fasciculata. Treatment with ACTH increased the apparent signal in both the glomerulosa and in fasciculata zones.

A low sodium diet initially enhanced the transcription signal specifically in the glomerulosa, but as the regime
\end{abstract}

was extended from 5 days to more than 2 weeks, the signal was also increased dramatically in the zona reticularis.

The results emphasize the potential importance of the intraglandular renin-angiotensin system, particularly under conditions of chronic stimulation. They also suggest that angiotensin II, as well as being the major regulator of the glomerulosa, may also have some role in inner adrenocortical zone functions.

Journal of Endocrinology (1998) 157, 217-223

\section{Introduction}

Although the renin-angiotensin system (RAS) has been primarily considered to be a circulating hormonal system, its presence in a variety of tissues locally has been well documented (Ganten et al. 1976, Campbell 1987, Deschepper \& Ganong 1988, Mulrow 1992). Renin-like activity has been detected in the adrenal glands of rat (Ryan 1967, Ganten et al. 1974, Naruse \& Inagami 1982, Doi et al. 1983, 1984a, Inagami et al. 1984, Nakamaru et al. 1985) and other species (Hayduk et al. 1970, Ganten et al. 1976, Naruse et al. 1983, 1984, Racz et al. 1992). Nephrectomy elicits a rapid and marked increase in the adrenal renin activity indicating that this enzyme is endogenous to the adrenal rather than due to contamination by plasma renin of renal origin (Naruse \& Inagami 1982, Doi et al. 1984a,b, Inagami et al. 1984). Further evidence for the adrenal production of renin comes from in vitro studies using adrenal capsular tissue explants (Shier et al. 1989) or rat adrenal glomerulosa cell cultures (Yamaguchi et al. 1990). Mizuno et al. (1988) suggested that renin is stored in the rat adrenal gland and that storage granules are released into the extracellular space in the same fashion as from the granules of the juxtaglomerular cells of the kidney.

Other components of the RAS, including angiotensinconverting enzyme (ACE) and angiotensinogen, have also been detected in the rat (Cushman \& Cheung 1971,
Mendelsohn 1984). The presence of ACE in the adrenal gland, and specifically within the capillary endothelial cells in the adrenal cortex, has been shown by immunocytochemistry and $\left[{ }^{3} \mathrm{H}\right]$ captopril autoradiography (Caldwell et al. 1976, Del Vecchio et al. 1980, Strittmatter et al. 1986). Angiotensinogen mRNA has also been detected in rat (Campbell \& Habener 1986, Ohkubo et al. 1986), mouse (Dzau et al. 1987) and human (Racz et al. 1992) adrenals, and using in situ hybridization, Campbell \& Habener (1989) demonstrated that angiotensinogen mRNA was present in the fibroblast-like cells immediately adjacent to the adrenal capsule of control rats, as well as in the adrenal itself (Campbell \& Habener 1986, 1987).

Although earlier studies showed (pro)renin gene expression in rat adrenals (Deschepper et al. 1986, Dzau et al. 1987), the precise localization of adrenal (pro)renin mRNA in normal adult rats is not yet entirely clear. Deschepper et al. (1986) used a mouse renin cDNA probe on rat adrenal sections, but obtained a high background of non-specific positive signal in their in situ hybridization data, though Brecher et al. (1989) were able to compare the amounts of (pro)renin mRNA detected in adrenal capsular tissue (zona glomerulosa) and decapsular tissue (inner cortex and medulla) from nephrectomized rats using dot blot hybridization, but inevitably without cellular precision. The present study, using rat renin antisense oligonucleotide for non-radioactive in situ hybridization, was designed to identify the precise localization of 
(pro)renin mRNA in normal female adult rat adrenals, and to study its regulation by adrenocorticotrophin (ACTH) administration and dietary sodium.

\section{Materials and Methods}

General laboratory chemicals and reagents were obtained from Sigma Chemical Company Ltd (Poole, Dorset, UK) and were molecular biology grade. B.D.H. (Poole, Dorset, UK) and Merck, Sharp and Dohme Ltd (Hoddesdon, Herts, UK) chemicals and solvents were Analar grade.

Adult female Wistar rats between 12 and 14 weeks of age and weighing 200-250 g, were obtained from established breeders and maintained briefly at Queen Mary and Westfield College. ACTH-treated rats, fed on a normal diet, were injected daily with Depot Synacthen (CibaGeigy, Horsham, Sussex, UK; $100 \mu \mathrm{g} / 100 \mu \mathrm{l}$ per animal, i.m.) for 1,3 or 5 days. The dosage of ACTH used here has been shown to have a good response in rat adrenals (Vazir et al. 1981). Control rats were similarly injected daily with $0.9 \%(\mathrm{w} / \mathrm{w}) \mathrm{NaCl}, 100 \mu \mathrm{l} /$ animal. Sodium-restricted rats were fed on wholemeal flour diet (Fattah et al. 1977) containing less than $0 \cdot 1 \%(\mathrm{w} / \mathrm{w}) \mathrm{NaCl}$, with added $1 \%$ (w/w) $\mathrm{CaCO}_{3}$ for 5 and 17 days. The same diet with $1 \%$ (w/w) $\mathrm{NaCl}$ added was used for dietary control rats. Five rats were used in each control or experimental group.

The antisense rat renin oligonucleotide probe was obtained commercially (Oncogene Science Inc., distributed by Cambridge BioScience, Cambridge, Cambs, UK), and enzymatically labelled with a digoxigenin (DIG)labelled nucleotide tail with incorporation of several DIGdUTP molecules at their $3^{\prime}$-end, using terminal transferase (Boehringer Mannheim, Lewes, Sussex, UK) to increase sensitivity, thus allowing the detection of small amounts of target mRNAs. The labelled probes were reconstituted in sterile water and stored at $-20{ }^{\circ} \mathrm{C}$ until used. Tissue preparations and hybridization methods were as previously described (Ho \& Vinson 1995). Both frozen and paraffin wax-embedded sections were used. In order to determine the optimal condition for in situ hybridization, a range of proteinase $\mathrm{K}$ concentrations were used. Sections $(8 \mu \mathrm{m})$ were digested by proteinase $\mathrm{K}(0 \cdot 625-5 \mu \mathrm{g} / \mathrm{ml}$; Boehringer Mannheim) for $30 \mathrm{~min}$ at $37^{\circ} \mathrm{C}$. RNasetreated control sections were incubated in pre-warmed
RNase cocktail (HT Biotechnology Ltd, Cambridge, Cambs, UK) for $90 \mathrm{~min}$ at $37^{\circ} \mathrm{C}$. Proteinase $\mathrm{K}$ and RNase reactions were stopped by post-fixation in $0.4 \%(\mathrm{w} / \mathrm{v})$ paraformaldehyde for $15 \mathrm{~min}$. Sections were acetylated by using $0 \cdot 25 \%(\mathrm{v} / \mathrm{v})$ acetic anhydride in $0.1 \mathrm{~mol} / 1$ triethanolamine (TEA) and $0.9 \%(\mathrm{w} / \mathrm{v}) \mathrm{NaCl}$ solution and incubated for $10 \mathrm{~min}$. After acetylation, sections were dehydrated and dried at room temperature. Sections were covered with hybridization buffer $(50 \%(\mathrm{v} / \mathrm{v})$ formamide, $10 \mathrm{mmol}$ Tris $/ \mathrm{l}, \mathrm{pH} 7 \cdot 5$, in $4 \times \mathrm{SSC}(1 \times \mathrm{SSC}$ contains $150 \mathrm{mmol} \mathrm{NaCl} / 1$ and $15 \mathrm{mmol}$ trisodium citrate/l), $1 \times$ Denhardt's solution, $500 \mu \mathrm{g}$ sheared salmon sperm DNA/ml, 10\% (v/v) dextran sulphate) containing DIGlabelled probes $(0 \cdot 5 \mathrm{pmol} / 15 \mu \mathrm{l}$ per section) and incubated overnight at $37^{\circ} \mathrm{C}$ in a humidified environment. The unhybridized probes were removed by washing the sections with decreasing concentrations of SSC for $40 \mathrm{~min}$ and for a further $15 \mathrm{~min}$ in Tris-buffered saline (TBS, $\mathrm{pH}$ $7 \cdot 6,50 \mathrm{mmol} / \mathrm{l})$ with added $0 \cdot 1 \%(\mathrm{v} / \mathrm{v})$ Triton X-100 and $0 \cdot 1 \%(\mathrm{w} / \mathrm{v})$ BSA at room temperature. The specific binding of oligonucleotide probes was detected by incubating the sections with alkaline phosphatase-conjugated sheep anti-DIG Fab fragments (Boehringer Mannheim) for $5 \mathrm{~h}$. Sections were washed in TBS followed by incubation with nitroblue tetrazolium (NBT, $330 \mu \mathrm{g} / \mathrm{ml}$ ) and 5-bromo-4-chloro-3-indolyl phosphate (BCIP, $165 \mu \mathrm{g}$ / $\mathrm{ml}$ ) in a dark, humidified environment. The optimal substrate incubation time for detecting adrenal (pro)renin mRNA was about $22 \mathrm{~h}$.

\section{Results}

It should be noted that the dark staining observed in the connective tissue capsule was considered to be nonspecific in nearly all cases. To ensure reproducibility of results, experiments were repeated a minimum of three times, with adrenals from five animals in each group on each occasion. A negative control is shown in Fig. 1. Since renin is produced by proteolytic cleavage from its precursor preprorenin, the renin mRNA detected in this investigation codes for the precursor rather than for active renin specifically.

A remarkable increase in both size and weight (more than $100 \%$, from a mean of approximately $70 \mathrm{mg}$ (control)

Figure 1 In situ hybridization using rat renin antisense oligonucleotide probe on RNase-pretreated rat adrenal section showing negative staining. $\mathrm{G}=$ zona glomerulosa, $\mathrm{F}=$ zona fasciculata, $\mathrm{R}=$ zona reticularis. $(\times 70)$

Figure 2 Localization of (pro)renin mRNA using in situ hybridization in control rat (a) cortex and (b) zona reticularis and medulla. Positive signals are shown by dark staining. $M=$ medulla. $(\times 140)$

Figure 3 Localization of (pro)renin mRNA using in situ hybridization in adrenal (a) cortex and (b) zona reticularis and medulla from rat treated with ACTH for 1 day. $(\times 140)$

Figure 4 Localization of (pro)renin mRNA using in situ hybridization in adrenal (a) cortex and (b) zona reticularis and medulla from rat treated with ACTH for 3 days. $(\times 140)$

Journal of Endocrinology (1998) 157, 217-223 


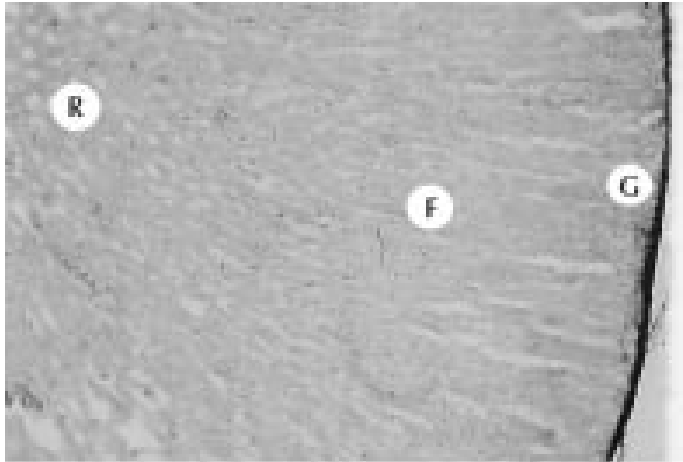

Fig. 1

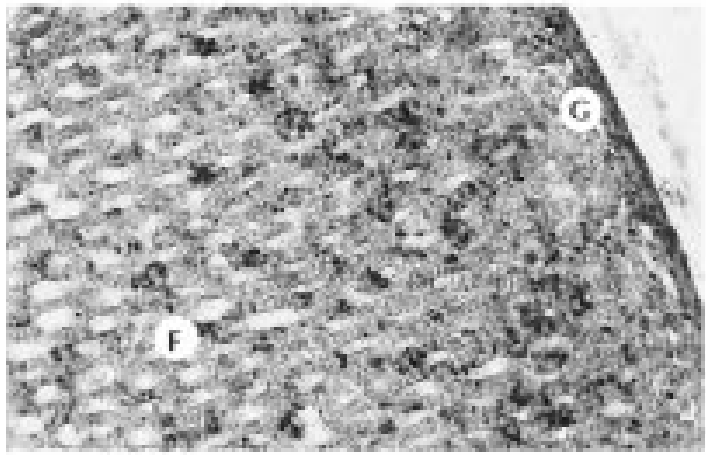

Fig. 2a

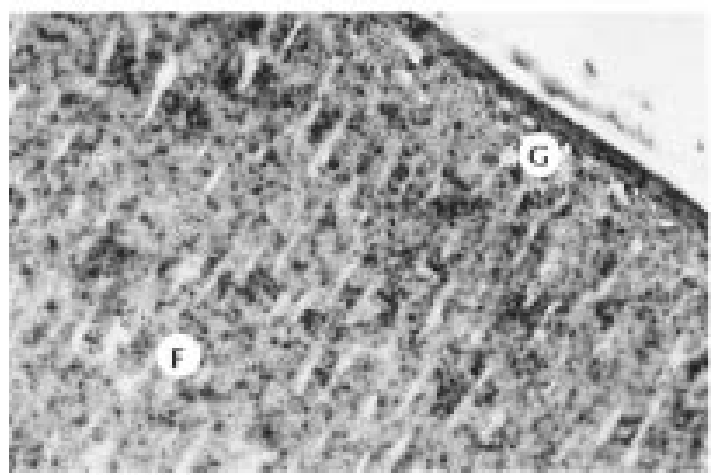

Fig. 3a

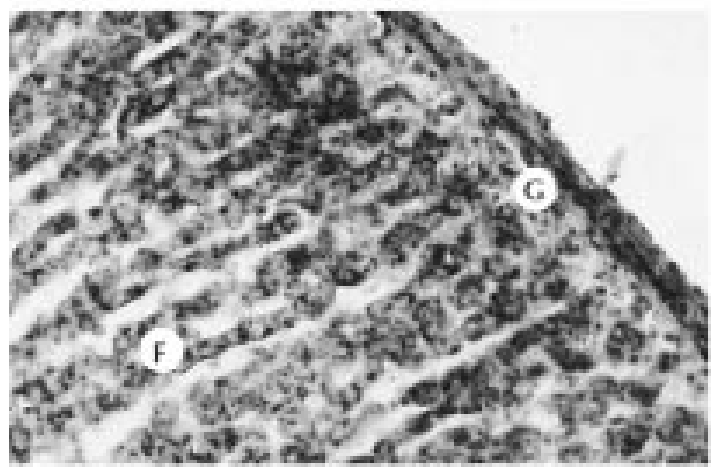

Fig. $4 \mathrm{a}$

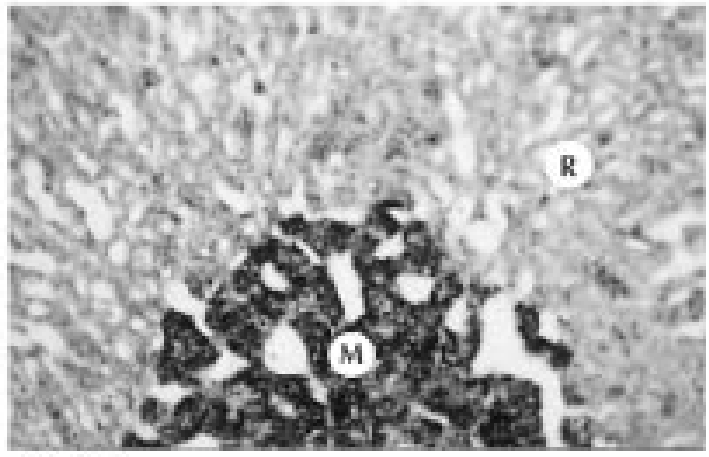

Fig. 2b

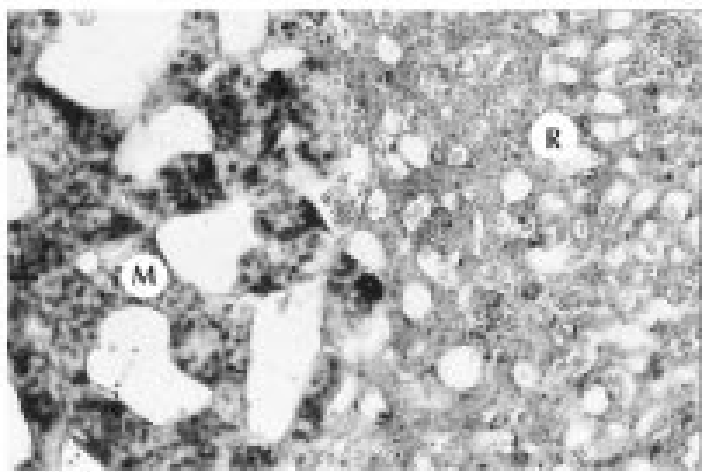

Fig, 3b

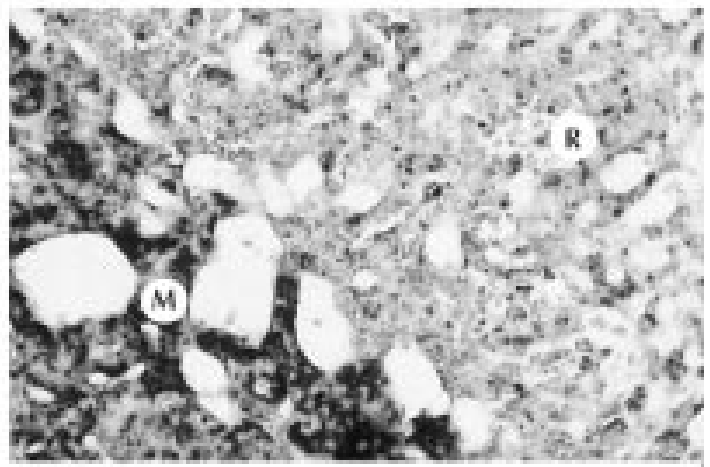

Fig. $4 \mathrm{~b}$ 
to $140-200 \mathrm{mg}$ (ACTH-treated) per gland pair) was observed in adrenals from rats treated for 3 or 5 days; these glands were intensely hyperaemic. In control, untreated animals small amounts of (pro)renin mRNA were detected in the adrenal cortex, predominantly in the zona fasciculata (Fig. 2a), whereas a much stronger signal was seen in the medulla (Fig. 2b). There was no observable change in the amount of (pro)renin mRNA detected in the inner cortex after 1 day of ACTH treatment, although the positive signal was at this stage also observed in the zona glomerulosa (Fig. 3). Further ACTH treatment for 3 or 5 days increased the (pro)renin mRNA in the entire adrenal cortex, and positive signals were detected in the subcapsular region as well as the inner cortex (Figs 4 and 5). Moreover, continuous administration of ACTH also gradually increased the amount of (pro)renin mRNA in the zona reticularis (Figs $4 \mathrm{~b}$ and $5 \mathrm{~b}$ ). The (pro)renin mRNA in the medulla was not altered by ACTH treatment (Figs $4 \mathrm{~b}$ and $5 \mathrm{~b}$ ).

Low sodium diet has no effect on ACTH or inner adrenocortical zone function (Vinson et al. 1992). The localization of (pro)renin mRNA was also changed remarkably in the sodium-restricted rat adrenal in which, after 5 days, a positive signal was observed only in the zona glomerulosa and some fasciculata cells next to the outer cortex (Fig. 6a). The amount of (pro)renin mRNA detected in the medulla was slightly reduced in these rats (Fig. 6b). After 17 days of dietary sodium restriction, a positive (pro)renin mRNA signal was seen in the reticularis as well as in the glomerulosa (Fig. 7).

\section{Discussion}

These observations demonstrate transcription of the (pro)renin gene and the localization of its mRNA in adult rat adrenal glands. In contrast with previous reports showing that (pro)renin mRNA and/or renin activity were detected predominantly in the zona glomerulosa of rat adrenals (Doi et al. 1984a, Deschepper et al. 1986, Brecher et al. 1989), the present data showed that in the normal adult female rat adrenal cortex, small amounts of (pro)renin mRNA were found predominantly in the outer zona fasciculata, but not in the zona glomerulosa (Fig. 2a). Although the significance of the local RAS in the adrenal inner cortex receives very little attention, it has been shown that long-term angiotensin II administration slightly stimulates the growth of the rat zona fasciculata, and increases plasma corticosterone concentration in vivo (Nussdorfer et al. 1981, Mazzocchi et al. 1985). Other reports also demonstrated that angiotensin II enhances the secretory activity of fasciculata cell preparations in other species in vitro (Hepp et al. 1977, McKenna et al. 1978, Pham-Huu-Trung et al. 1981), while McEwan et al. (1996) showed that angiotensin II, like a low sodium diet, increased cell proliferation in the reticularis as well as in the glomerulosa. It is, of course, well documented that angiotensin II is a specific zona glomerulosa stimulant and an important regulator of aldosterone secretion in most mammalian species (Glöz \& Sugar 1962, Müller 1988). However, angiotensin II receptors are also found in rat adrenocortical inner zones though at a lower concentration than in the glomerulosa (Douglas et al. 1978). Thus it is possible that the local RAS may play a role in the regulation of the growth and functions of the adrenal inner cortex, and these possibilities are given further support by our studies on the actions of ACTH and a low sodium diet. The functions of the inner adrenal cortex are thought to be controlled almost exclusively by ACTH. Nevertheless, adrenal renin is also influenced by ACTH (Ganten et al. 1974) and administration of ACTH to normal rats significantly increases adrenal renin content (Doi et al. 1984a), while, in vitro, ACTH increases renin activity in cultured rat glomerulosa cells (Yamaguchi et al. 1992). The present results also show that adrenal (pro)renin gene expression was enhanced by ACTH administration in vivo (Figs 3-5), and that this induction occurs throughout the cortex. Although the physiological significance of ACTHinduced renin activity in the adrenal gland is not entirely clear, the results certainly suggest that it has a role both in inner zone as well as glomerulosa function.

This concept is supported by the effects of sodium depletion. Early work by Deane et al. (1948) showed that sodium deficiency causes widening of the adrenal glomerulosa with cellular hypertrophy and hyperplasia. It stimulates both systemic and local adrenal RASs and induces a gradual hypertrophy of the endoplasmic reticulum, Golgi network and the mitochondrial compartment of rat glomerulosa cells in vivo (Mazzocchi et al. 1985, Robba et al. 1988). Aguilera \& Catt (1978) also reported that a low sodium diet enhances the glomerulosa aldosterone response to a chronic infusion of angiotensin II. Sodium-depleted diets also increase adrenal renin as well as aldosterone secretion, while a high sodium diet decreases both (Ganten et al. 1974, Doi et al. 1983, 1984a, Nakamaru et al. 1985), and these effects have been attributed to the increase in activity of the local RAS (Aguilera \& Catt 1978). The adrenal RAS, which is stimulated by low sodium intake (Kifor et al. 1991, Chiou et al. 1995), is thought to enhance the responsiveness of the glomerulosa cells to circulating angiotensin II and results in a maximal increase in aldosterone secretion (Menachery et al. 1991). This hypothesis supports earlier observations that the prior use of an ACE inhibitor prevents the zona glomerulosa responsiveness to angiotensin II (Müller et al. 1984) and the hypertrophy of glomerulosa cells (Mazzocchi \& Nussdorfer 1984) in sodium-restricted rats. The present observations certainly support the view that the zona glomerulosa was the main site for (pro)renin synthesis in sodium-restricted rats (Fig. 6a). These results are, as may be expected, somewhat different from those obtained with ACTH treatment. Nevertheless, it is 


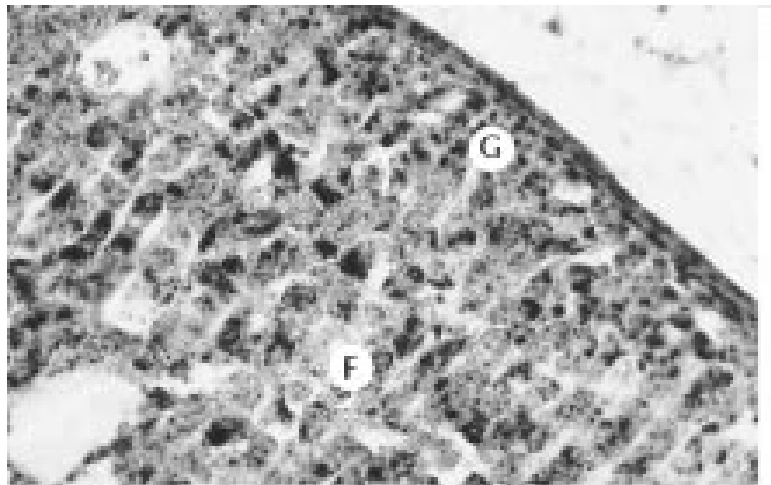

Fig. 5 a

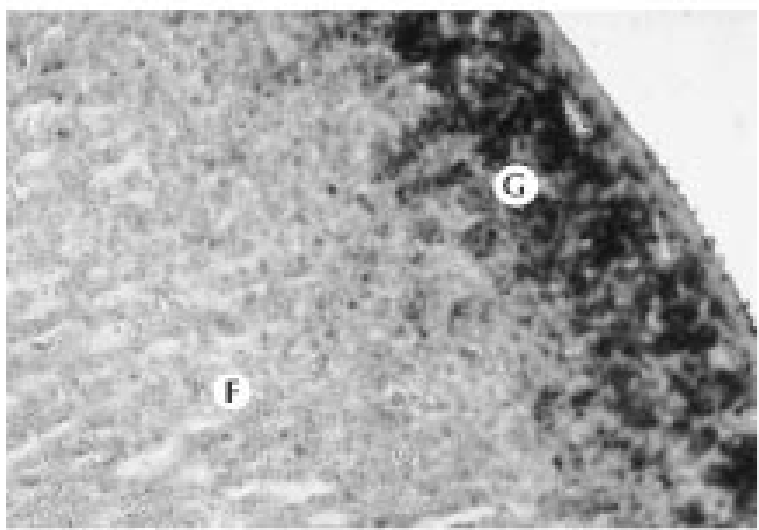

Fig. $6 \mathrm{a}$

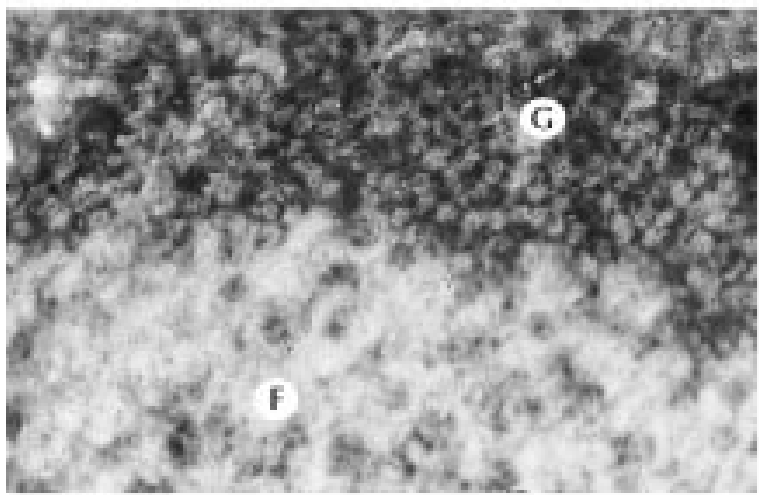

Fig. $7 \mathrm{a}$

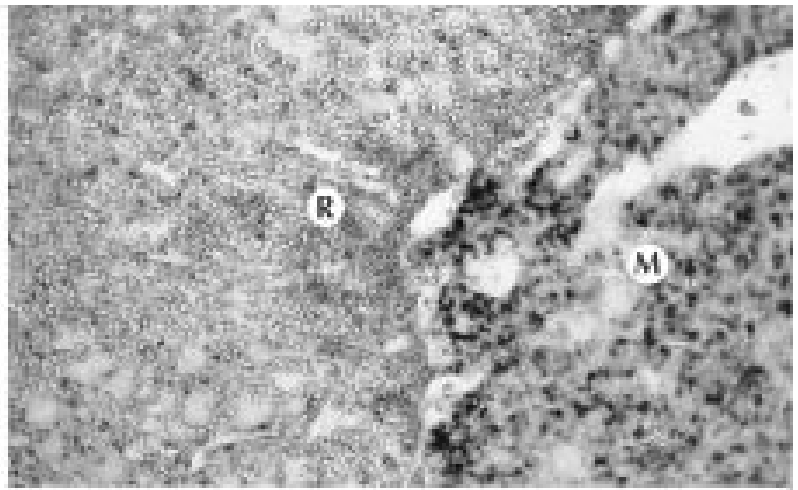

Fig. 5b

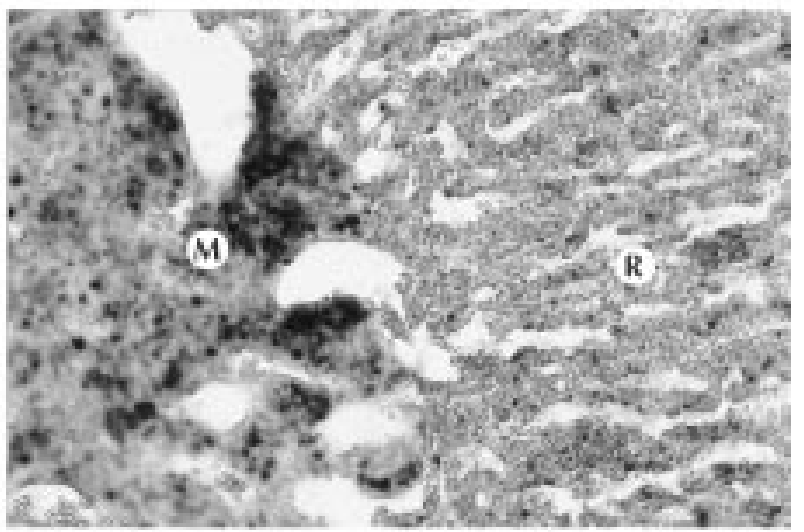

Fig. $6 b$

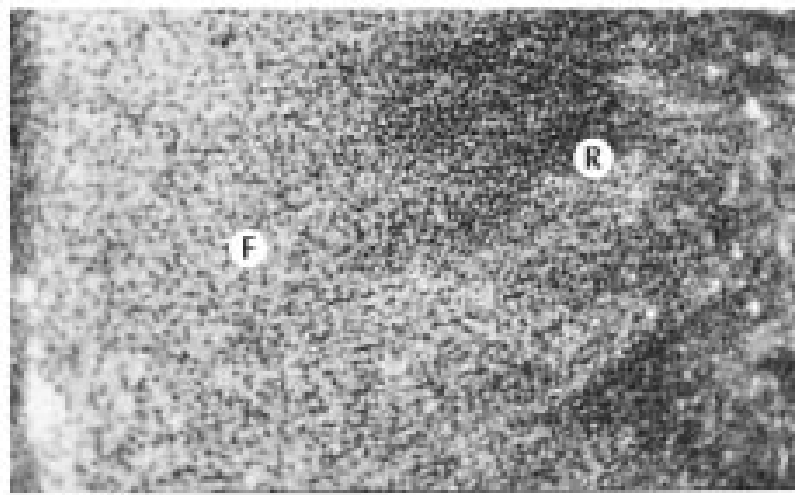

Fig. $7 b$

Figure 5 Localization of (pro)renin mRNA using in situ hybridization in adrenal (a) cortex and (b) zona reticularis and medulla from rat treated with ACTH for 5 days. $(\times 140)$

Figure 6 Localization of (pro)renin mRNA using in situ hybridization in adrenal (a) cortex and (b) zona reticularis and medulla from rat subjected to dietary sodium depletion for 5 days. $(\times 140)$

Figure 7 Localization of (pro)renin mRNA using in situ hybridization in frozen adrenal (a) cortex and (b) zona reticularis and medulla from rat subjected to dietary sodium depletion for 17 days. $(a=\times 280, b=\times 70)$

important to emphasize that both of these treatments, ACTH and low sodium, affect (pro)renin transcription throughout the gland, and it is particularly striking that a more prolonged low sodium diet enhanced the (pro)renin mRNA signal in reticularis cells as well as in the glomerulosa. This accords with the observation by McEwan et al. 
(1996) that a low sodium diet, like angiotensin II treatment, increases proliferation in the reticularis as well as in the glomerulosa. The results emphasize the potential importance of the tissue RAS, perhaps particularly in extreme conditions of stimulation, such as in the regulation of adrenocortical function.

In this study significant amounts of (pro)renin mRNA were detected in the adrenal medulla in both control and stimulated conditions (Figs 2b-6b). As early as 1967, Ryan suggested that renin might act as a local hormone in modulating adrenal medullary catecholamine secretion. Renin and its mRNA have been detected in human phaeochromocytoma cells (Racz et al. 1992), and ACE is localized in the rat adrenal medulla (Strittmatter et al. 1986). In addition, angiotensin II binding sites have been found in membrane homogenates of rat adrenal medulla (Healy et al. 1985). Stimulation of angiotensin receptors on adrenal medullary cells increases the influx of calcium (Zimlichman et al. 1987), and causes translocation of protein kinase $\mathrm{C}$ from soluble to particulate fractions (Stachowiak et al. 1990, 1991). Angiotensin II induces c-fos expression in adrenal medullary cells in vivo and in vitro (Stachowiak et al. 1990). It also has the ability to influence the activity of the sympathetic nervous system, and since it stimulates catecholamine biosynthesis (Lewis \& Reit 1965) and release (Robinson 1967, Peach 1977) in the adrenal medulla. The local RAS may play a role in the regulation of catecholamine excretion. It is clear, however, that its regulation is quite different from that of the cortex, since (pro)renin gene transcription in the medulla was relatively unaffected by the treatments that so clearly changed the distribution of the transcription of this gene in the cortex.

\section{References}

Aguilera G \& Catt KJ 1978 Regulation of aldosterone secretion by the renin-angiotensin system during sodium restriction in rats. Proceedings of the National Academy of Sciences of the USA $\mathbf{7 5}$ 4057-4061.

Brecher AS, Shier DN, Dene H, Wang SM, Rapp JP, Franco Saenz R \& Mulrow PJ 1989 Regulation of adrenal renin messenger ribonucleic acid by dietary sodium chloride. Endocrinology 124 2907-2913.

Caldwell PRB, Seegal BC, Das M \& Soffer RL 1976 Angiotensinconverting enzyme: vascular endothelial localisation. Science 191 1050-1051.

Campbell DJ 1987 Circulating and tissue angiotensin system. Journal of Clinical Investigation 79 1-6.

Campbell DJ \& Habener JF 1986 Angiotensinogen gene is expressed and differentially regulated in multiple tissues of the rat. Journal of Clinical Investigation 78 31-39.

Campbell DJ \& Habener JF 1987 Regional distribution of angiotensinogen messenger RNA in rat adrenal and kidney. Journal of Hypertension 4 S385.

Campbell DJ \& Habener JF 1989 Hybridization in situ studies of angiotensinogen gene expression in rat adrenal and lung. Endocrinology 124 218-222.
Chiou CY, Williams GH \& Kifor I 1995 Study of the rat adrenal renin-angiotensin system at a cellular level. Journal of Clinical Investigation 96 1375-1381.

Cushman DW \& Cheung HS 1971 Concentration of angiotensinconverting enzyme in tissues of the rat. Biochimica et Biophysica Acta 250 261-265.

Deane HW, Shaw JH \& Greep RO 1948 The effect of altered sodium or potassium intake on the width and cytochemistry of the zona glomerulosa of the rat's adrenal cortex. Endocrinology $\mathbf{4 3}$ 133-153.

Del Vecchio PJ, Ryan JW, Chung A \& Ryan US 1980 Capillaries of the adrenal cortex posses aminopeptidase A and angiotensinconverting enzyme activities. Biochemical Journal 186 605-612.

Deschepper CF \& Ganong WF 1988 Renin and angiotensin in endocrine glands. Frontiers of Neuroendocrinology 10 79-98.

Deschepper CF, Mellon SH, Cumin F, Baxter JD \& Ganong WF 1986 Analysis by immunocytochemistry and in situ hybridization of renin and its mRNA in kidney, testis, adrenal and pituitary of the rat. Proceedings of the National Academy of Sciences of the USA $\mathbf{8 3}$ $7552-7556$.

Doi Y, Atarashi K, Franco Saenz R \& Mulrow PJ 1983 Adrenal renin: a possible regulator of aldosterone production. Clinical and Experimental Hypertension A5 1119-1126.

Doi Y, Franco Saenz R \& Mulrow PJ 1984a Evidence for an extrarenal source of inactive renin in rats. Hypertension 6 627-632.

Doi Y, Atarashi K, Franco Saenz R \& Mulrow PJ $1984 b$ Effect of changes in sodium or potassium balance and nephrectomy on adrenal renin and aldosterone concentrations. Hypertension 6 1124-1129.

Douglas J, Aguilera G, Kondo T \& Catt K 1978 Angiotensin II receptors and aldosterone production in rat adrenal glomerulosa cells. Endocrinology 102 685-696.

Dzau VJ, Ellison KE, Brody T, Ingelfinger J \& Pratt RE 1987 A comparative study of the distributions of renin and angiotensinogen messenger ribonucleic acids in rat and mouse tissues. Endocrinology $1202334-2338$.

Fattah DI, Whitehouse BJ \& Vinson GP 1977 Biosynthesis of aldosterone from 18-hydroxylated precursors by rat adrenal tissue in vitro. Journal of Endocrinology 75 187-195.

Ganten D, Ganten U, Kubo S, Granger P, Nowaczynski W, Boucher R \& Genest J 1974 Influence of sodium, potassium and pituitary hormones on iso-renin in rat adrenal glands. American Journal of Physiology 227 224-229.

Ganten D, Hutchinson JS, Schelling P, Ganten U \& Fischer H 1976 The iso-renin angiotensin systems in extra-renal tissue. Clinical and Experimental Pharmacology and Physiology 3 102-126.

Glöz E \& Sugar K 1962 The effect of synthetic angiotensin II on the synthesis of aldosterone in the adrenals. Journal of Endocrinology 24 299-302.

Hayduk K, Boucher R \& Genest J 1970 Renin activity content in various tissues of dog under different physiopathological states. Proceedings of the Society for Experimental Biology and Medicine 134 252-255.

Healy DP, Maciejewski AR \& Printz MP 1985 Autoradiographic localization of angiotensin II binding sites in the rat adrenal gland. Endocrinology 116 1221-1223.

Hepp R, Grillet C, Peytremann A \& Vallotton MB 1977 Stimulation of corticosteroid biosynthesis by angiotensin I [Des-Asp1]angiotensin I, angiotensin II and [Des-Asp]-angiotensin II in bovine adrenal fasciculata cells. Endocrinology 101 717-725.

Ho MM \& Vinson GP 1995 Endocrine control of the distributions of bFGF, IGF-I and TGF-beta1 mRNAs in adult rat adrenals using non-radioactive in situ hybridization. Journal of Endocrinology 144 379-387.

Inagami T, Pandey K, Nakamaru M, McKenzie C, Misono KS, Naruse K \& Naruse M 1984 Advances in the biochemistry of the renin-angiotensin system: intracellular renin-angiotensin system in 
rat adrenal zona glomerulosa cells and rat testicular Leydig cells. In Endocrinology, pp 399. Eds F Labrie \& L Proulx. Amsterdam: Elsevier Science Publishers.

Kifor I, Moor TJ, Fallo F, Sperling E, Menachery A, Chiou CY \& Williams GH 1991 The effect of sodium intake on angiotensin content of the rat adrenal gland. Endocrinology 128 1277-1284.

Lewis GP \& Reit E 1965 The action of angiotensin and bradykinin on the superior cervical ganglion of the cat. Journal of Physiology 179 538-553.

McEwan PC, Lindop GB \& Kenyon CJ 1996 Control of cellproliferation in the rat adrenal gland in vivo by the reninangiotensin system. American Journal of Physiology, Endocrinology and Metabolism 34 E192-E198.

McKenna TJ, Island DP, Nicholson WE \& Liddle GW 1978 Angiotensin stimulates cortisol biosynthesis in human adrenal cells. Steroids 32 127-136.

Mazzocchi G \& Nussdorfer GG 1984 Long-term effects of captopril on the morphology of normal rat adrenal zona glomerulosa. Experimental and Clinical Endocrinology 84 148-152.

Mazzocchi G, Rebuffat P, Robba C, Malendowicz LK \& Nussdorfer GG 1985 Trophic effects of potassium loading on the rat zona glomerulosa: permissive role of ACTH and angiotensin II. Acta Endocrinologica 108 98-103.

Menachery A, Braley LM, Kifor I, Gleason R \& Williams GH 1991 Dissociation in plasma renin and adrenal ANG II and aldosterone responses to sodium restriction in rats. American Journal of Physiology 261 E487-E494.

Mendelsohn FA 1984 Localisation of angiotensin-converting enzyme in rat forebrain and other tissues by in vitro autoradiography using ${ }^{125}$ I-labelled MK351A. Clinical and Experimental Pharmacology and Physiology 11 431-435.

Mizuno K, Hoffman LH, McKenzie JC \& Inagami T 1988 Presence of renin secretory granules in rat adrenal gland and stimulation of renin secretion by angiotensin II but not by adrenocorticotropin. Journal of Clinical Investigation 82 1007-1016.

Mulrow PJ 1992 Adrenal renin: regulation and function. Frontiers of Neuroendocrinology 13 47-60.

Müller J 1988 Alterations in aldosterone biosynthesis and secretion in long-term experiments and diseases. In Regulation of Aldosterone Biosynthesis, pp 108-110. Ed J Müller. Berlin: Springer-Verlag.

Müller J, Hofstetter L, Schwenderner-Canlas P, Brunner DB \& Lund EG 1984 Role of the renin-angiotensin system in the regulation of late steps in aldosterone biosynthesis by sodium intake of potassiumdeficient rats. Endocrinology 115 350-356.

Nakamaru M, Misono KS, Naruse M, Workman J \& Inagami T 1985 A role of the adrenal renin-angiotensin system in the regulation of potassium-stimulated aldosterone production. Endocrinology 117 1772-1778

Naruse M \& Inagami T 1982 Markedly elevated specific renin levels in the adrenal in genetically hpertensive rats. Proceedings of the National Academy of Sciences of the USA 79 3295-3299.

Naruse M, Sussman CR, Nause K, Jackson RV \& Inagami T 1983 Renin exists in human adrenal tissue. Journal of Clinical Endocrinology and Metabolism 57 482-487.

Naruse M, Naruse K, Inagaki T \& Inagami T 1984 Immunoreactive renin in mouse adrenal gland: localisation in the inner cortical region. Hypertension 6 275-280.

Nussdorfer GG, Robba C, Mazzochi G \& Rebuffat P 1981 Effects of angiotensin II on the zona fasciculata of the rat adrenal cortex: an ultrastructural stereologic study. Journal of Anatomy 132 235-242.

Ohkubo H, Nakayama K, Tanaka T \& Nakanishi S 1986 Tissue distribution of rat angiotensinogen mRNA and structural analysis of its heterogeneity. Journal of Biological Chemistry 261 319-323.
Peach MJ 1977 The renin-angiotensin system. Physiological Reviews 57 313-370.

Pham-Huu-Trung MT, Lombes M, Bogyo A \& Girard F 1981 Combined effects of angiotensin II and ACTH on cortisol production: in vitro studies on isolated guinea-pig adrenal cells. Journal of Steroid Biochemistry 14 929-934.

Racz K, Pinet F, Gasc JM, Guyene TT \& Corvol P 1992 Coexpression of renin, angiotensinogen, and their messenger ribonucleic acids in adrenal tissues. Journal of Clinical Endocrinology and Metabolism 75 730-737.

Robba C, Rebuffat P, Mazzocchi G \& Nussdorfer GG 1988 Long-term trophic effect of sodium restriction on the rat adrenal zona glomerulosa. I. Its partial independence of the reninangiotensin system. Experimental and Clinical Endocrinology 91 43-50.

Robinson RL 1967 Stimulation of the catecholamine output of the isolated, perfused adrenal gland of the dog by angiotensin and bradykinin. Journal of Pharmacology and Experimental Therapeutics 156 252-257.

Ryan JW 1967 Renin-like enzyme in the adrenal gland. Science 158 1589-1590.

Shier DN, Kusano E, Stoner GD, Franco Saenz R \& Mulro PJ 1989 Production of renin, angiotensin II and aldosterone by adrenal explant cultures: response to potassium and converting enzyme inhibition. Endocrinology 125 486-491.

Stachowiak MK, Sar M, Touminen RK, Jiang HK, An S, Iadarola MJ, Poisner AM \& Hong JS 1990 Stimulation of adrenal medullary cells in vivo and in vitro induces expression of c-fos proto-oncogene. Oncogene 5 69-73.

Stachowiak MK, Poisner AM, Jiang HK, Hudson PH \& Hong JS 1991 Regulation of proenkephalin gene expression by angiotensin in bovine adrenal medullary cells: molecular mechanisms and nature of the second messenger systems. Molecular and Cellular Neuroscience 2 213-220.

Strittmatter SM, Desouza EB, Lynch DR \& Snyder SH 1986 Angiotensin-converting enzyme localized in the rat pituitary and adrenal glands by $[3 \mathrm{H}]$ captopril autoradiography. Endocrinology 118 1690-1699.

Vazir H, Whitehouse BJ, Vinson GP \& McCredie E 1981 Effects of prolonged ACTH treatment on adrenal steroidogenesis and blood pressure in rats. Acta Endocrinologica 97 533-542.

Vinson GP, Whitehouse BJ \& Hinson J 1992 The Adrenal Cortex. Prentice Hall, Englewood Cliffs: New Jersey.

Yamaguchi T, Naito Z, Stoner GD, Franco Saenz R \& Mulrow PJ 1990 Role of the adrenal renin-angiotensin system on adrenocorticotropic hormone- and potassium-stimulated aldosterone production by rat adrenal glomerulosa cells in monolayer culture. Hypertension 16 635-641.

Yamaguchi T, Tokita Y, Ranco Saenz R, Mulrow PJ, Peters J \& Ganten D 1992 Zonal distribution and regulation of adrenal renin in a transgenic model of hypertension in the rat. Endocrinology 131 1955-1962.

Zimlichman R, Goldstein DS, Zimlichman S, Stull R \& Keiser HR 1987 Angiotensin II increases cytosolic calcium and stimulates catecholamine release in cultured bovine adrenomedullary cells. Cell Calcium 8 315-325.

Received 27 August 1997

Revised manuscript received 21 November 1997 Accepted 25 November 1997 